\title{
Nitrogen acquisition in Agave tequilana from degradation of endophytic bacteria
}

SUBJECT AREAS:

MICROBIOLOGY

PLANT SYMBIOSIS

ECOLOGY

Received

16 January 2014

Accepted

20 October 2014

Published

6 November 2014

Correspondence and requests for materials should be addressed to

J.F.W. (white@rci. rutgers.edu) or P.D.M. (pdmascio@iq.usp.br)
Miguel J. Beltran-Garcia ${ }^{1,3}$, James F. White, Jr. ${ }^{2}$, Fernanda M. Prado ${ }^{3}$, Katia R. Prieto ${ }^{3}$, Lydia F. Yamaguchi ${ }^{4}$, Monica S. Torres ${ }^{2}$, Massuo J. Kato ${ }^{4}$, Marisa H. G. Medeiros ${ }^{3} \&$ Paolo Di Mascio ${ }^{3}$

'Departamento de Química ICET, Universidad Autonoma de Guadalajara, Patria 1201, Lomas del Valle, Zapopan Jalisco, Mexico, ${ }^{2}$ Department of Plant Biology and Pathology, Rutgers University, New Brunswick, NJ USA, ${ }^{3}$ Departamento de Bioquímica, Instituto de Química, Universidade de São Paulo, 05508-000, São Paulo, SP, Brazil, ${ }^{4}$ Departamento de Química Fundamental, Instituto de Química, Universidade de São Paulo, 05508-000, São Paulo, SP, Brazil.

Plants form symbiotic associations with endophytic bacteria within tissues of leaves, stems, and roots. It is unclear whether or how plants obtain nitrogen from these endophytic bacteria. Here we present evidence showing nitrogen flow from endophytic bacteria to plants in a process that appears to involve oxidative degradation of bacteria. In our experiments we employed Agave tequilana and its seed-transmitted endophyte Bacillus tequilensis to elucidate organic nitrogen transfer from ${ }^{15} \mathrm{~N}$-labeled bacteria to plants. Bacillus tequilensis cells grown in a minimal medium with ${ }^{15} \mathrm{NH}_{4} \mathrm{Cl}$ as the nitrogen source were watered onto plants growing in sand. We traced incorporation of ${ }^{15} \mathrm{~N}$ into tryptophan, deoxynucleosides and pheophytin derived from chlorophyll a. Probes for hydrogen peroxide show its presence during degradation of bacteria in plant tissues, supporting involvement of reactive oxygen in the degradation process. In another experiment to assess nitrogen absorbed as a result of endophytic colonization of plants we demonstrated that endophytic bacteria potentially transfer more nitrogen to plants and stimulate greater biomass in plants than heat-killed bacteria that do not colonize plants but instead degrade in the soil. Findings presented here support the hypothesis that some plants under nutrient limitation may degrade and obtain nitrogen from endophytic microbes.

ike all living things, plants require nitrogen $(\mathrm{N})$ throughout their development. The $\mathrm{N}$ incorporated as $\mathrm{NO}_{3}$ and $\mathrm{NH}_{4}{ }^{+}$represents about $2 \%$ of total plant dry matter, and is a component of proteins, nucleic acids, cofactors, signalling molecules, storage and numerous plant secondary products. The availability of $\mathrm{N}$ to plant roots is often an important limiting factor for plant growth. Plants obtain $\mathrm{N}$ from nitrogen fixing bacteria and decomposition of dead tissues of both plants and animals by microorganisms ${ }^{1-5}$. Moreover, a tiny fraction $(0.00024 \%)$ of planetary $\mathrm{N}$ is available to plants in soils, where plants compete with microbes to absorb $\mathrm{N}^{6}$. The atmospheric formation of nitrate by photo-oxidation through the effect of lightning also is minimal ${ }^{9,10}$. The limited bioavailability of $\mathrm{N}$, and the need to enhance crop growth, have provoked a continual expansion in use of $\mathrm{N}$ fertilizer with from 12 to 104 additional teragrams used each year ${ }^{7,8}$. On average only $30-50 \%$ of the applied $\mathrm{N}$ is taken up by plants, with the remainder being lost to surface run-off, leaching of nitrates and ammonia volatilization $^{11}$. The excessive use of fertilizers is a highly contaminating process ${ }^{9}$ and the energy required to produce $\mathrm{N}$ through the Haber-Bosch process requires at least $1 \%$ of the world annual energy supply ${ }^{12}$.

Historically, it was thought that plants derived all $\mathrm{N}$ nutrition from the inorganic forms of $\mathrm{N}, \mathrm{NO}_{3}{ }^{-}$and $\mathrm{NH}_{4}{ }^{+}$. However, it is now known that the principal form of $\mathrm{N}$ entering soils that do not receive inorganic fertilizer is organic $\mathrm{N}$ derived from microbial breakdown of organic matter, including amino acids, di- and tri-peptides, DNA and proteins ${ }^{13-15}$. In addition, some plants can scavenge organic $\mathrm{N}$ from insects (carnivorous plants) or by entomopathogenic fungus-mediated $\mathrm{N}$ translocation from insects ${ }^{16,17}$. Further, some plants have been shown to consume and degrade bacteria and yeasts through endocytosis ${ }^{3}$. However, it is unclear whether endocytosis of microbes by plants is a purely defensive process or rather is a means to acquire nutrients $\mathrm{s}^{3-5}$. Plants are naturally colonised by endophytic bacteria that inhabit internal spaces without deleterious effects on host plants ${ }^{1,2}$. Endophytic bacteria that spend some time in soil enter roots or shoots and may spread to all plant tissues, often transmitting in seeds, thus ensuring transfer to the next plant generation ${ }^{2}$. However, controversy exists regarding the significance of nitrogen-fixing endophytes in plants ${ }^{1,2}$. It is frequently argued that positive effects of bacteria on plant growth may be the result of auxins and other growth regulators rather than enhanced $\mathrm{N}$ acquisition due to microbial $\mathrm{N}$ fixation ${ }^{18-21}$. Also there is no clear evidence as to how $\mathrm{N}$ is transferred from endophytic diazotrophs to the host plant. It has been suggested that $\mathrm{N}$ transfer to the host is via amino acids, ammonia, small organic 
molecules or mineralization of dead bacterial cells $\mathrm{s}^{22}$. Whether $\mathrm{N}$ is actually transferred from endophytic bacteria to plant host has proven difficult to resolve. The question of the mechanism of transfer of $\mathrm{N}$ from endophyte to host plant is an important gap in our knowledge. One possible mechanism for $\mathrm{N}$ transfer to host is that plants may scavenge organic nitrogen by oxidation and degradation of endophytic bacteria or their proteins using reactive oxygen species (ROS) to lyse cells and denature proteins. This mechanism has been termed 'oxidative nitrogen scavenging' ${ }^{4,23}$. The experiments reported here were done to evaluate whether ${ }^{15} \mathrm{~N}$ incorporated into bacterial endophyte biomolecules such as proteins and nucleic acids could be traced into plant molecules; and whether the transfer process involves evidence of oxidative degradation of microbes.

\section{Results}

${ }^{15} \mathrm{~N}_{2}$ gas assimilation into seedlings. Shoots of seedlings grown in ${ }^{15} \mathrm{~N}_{2}$-enriched air showed higher $\delta{ }^{15} \mathrm{~N}$ vs air content $(54.93 \pm 5.65 \delta$ ${ }^{15} \mathrm{~N}$ vs (\%o); mean \pm standard error of mean) than shoots from seedlings grown in non-enriched air $\left(3.07 \pm 1.12 \delta{ }^{15} \mathrm{~N} v s(\%)\right)$. This large difference in the ${ }^{15} \mathrm{~N} /{ }^{14} \mathrm{~N}$ ratios between the two treatments shows that $\mathrm{N}$ was fixed in the seedling tissues.

Bacillus tequilensis endophyte. For use in our tests to evaluate ${ }^{15} \mathrm{~N}$ transfer/translocation from bacterial endophyte to plant, we isolated an endophyte from seeds, seedlings and young plantlets (bulbillos) of Agave tequilana Weber, and identified it as endospore-forming Bacillus tequilensis (accession number KF792125) ${ }^{24}$ (Fig. 1) using sequence data. Bacillus tequilensis was present in both roots (Fig. 1C) and shoots of the host plant.

Visualization of bacteria in plant tissues. In seedling infection experiments using $B$. tequilensis we observed intracellular colonization by the bacterium into meristems and root epidermal cells of seedlings (Fig. 1A and 1B) and young plantlets. We further observed oxidation of bacterial cells within and on the surface of root epidermal cells (Fig. 1B and 1D) ${ }^{25}$.

\section{Experiment 1}

${ }^{15} \mathrm{~N}$ tracking experiments. A significant difference $(\mathrm{p}<0.05)$ was observed in ${ }^{15} \mathrm{~N}$-labeled tryptophan $\left({ }^{15} \mathrm{~N}\right.$-Trp) concentration between the controls $\left(\mathrm{H}_{2} \mathrm{O}\right.$ and unlabeled B. tequilensis, $\left.{ }^{14} \mathrm{~N}-B t e q\right)$ and plants inoculated with ${ }^{15} \mathrm{~N}$-labeled B. tequilensis $\left({ }^{15} \mathrm{~N}\right.$-Bteq $) .{ }^{15} \mathrm{~N}$ -

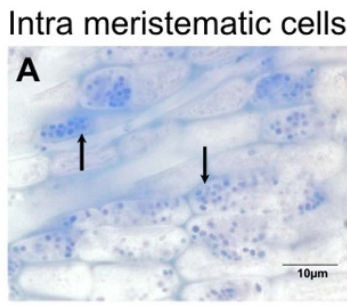

\section{Intra root cells}

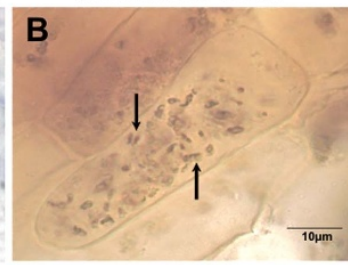

In culture

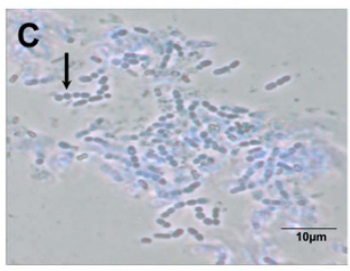

\section{On root surface}

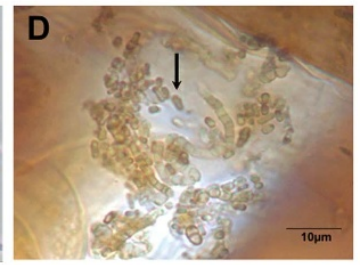

Figure $1 \mid$ Bacillus tequilensis: an endophyte of Agave tequilana.

Intracellular bacteria in meristematic root cells (A) and oxidation within root cortical cell (B), detail of cell morphology of the isolate grown on TSA medium (C), and bacteria on root surface showing $\mathrm{H}_{2} \mathrm{O}_{2}$ concentrations (brown) around bacterial cells (D). labeled Trp in the ${ }^{15} \mathrm{~N}$-Bteq treated plants was about 16 -fold higher $(21.05 \pm 5.47 \mathrm{ng} / \mathrm{mg})$ than ${ }^{14} \mathrm{~N}$-Bteq treated $(1.32 \pm 0.40 \mathrm{ng} / \mathrm{mg})$ and $\mathrm{H}_{2} \mathrm{O}$ treated plants (1.36 ng/mg) (Fig. 2, and Supplementary Fig. S5). Further quantification of ${ }^{15} \mathrm{~N}$-Trp demonstrated that plants supplemented with ${ }^{15} \mathrm{NH}_{4} \mathrm{Cl}$ had higher levels than plants supplemented with $\mathrm{H}_{2} \mathrm{O}$ or ${ }^{14} \mathrm{NH}_{4} \mathrm{Cl}$ (Supplementary Fig. S1). We detected tryptophan by high-performance liquid chromatography coupled to mass spectrometry in tandem (HPLC-MS/MS), although this amino acid was not quantified (Supplementary Fig. S4) $)^{26-28}$

Nitrogen incorporation into tissues of $A$. tequilana was also confirmed by HPLC-MS/MS detection of ${ }^{15} \mathrm{~N}$-labeled nucleosides (Fig. 3). Additionally, the same ${ }^{15} \mathrm{~N}$-labeled nucleosides were detected from A. tequilana supplemented with ${ }^{15} \mathrm{~N}$-labeled $\mathrm{NH}_{4} \mathrm{Cl}$ (Supplementary Fig. S9). Detection of $2^{\prime}$-deoxynucleosides methylated as 5-methyl-2' -deoxycytidine $\left({ }^{15} \mathrm{~N}_{3}\right.$ - MedC) and $N^{\prime}$-methyl- $2^{\prime}$ deoxyadenosine $\left({ }^{15} \mathrm{~N}_{5}\right.$-MedA) was also observed in plants of $A$. tequilana supplemented with ${ }^{15} \mathrm{~N}$-labeled $B$. tequilensis or $15 \mathrm{~N}$-labeled $\mathrm{NH}_{4} \mathrm{Cl}$ (Supplementary Fig. S10 and 11).

Pheophytin analysis. Analysis of unlabeled pheophytin a (Fig. 4B $)^{26,27}$ showed a distribution of isotope peaks in agreement with the theoretical values of this molecular formula $\left(\mathrm{C}_{55} \mathrm{H}_{74} \mathrm{~N}_{4} \mathrm{O}_{5}\right.$, $\left.[\mathrm{M}+\mathrm{H}]^{+}=871.5731\right)$ containing a base peak with $\mathrm{m} / z 871.5739$ (Fig. 4B). Incubation of $A$. tequilana with the ${ }^{15} \mathrm{~N}$-labeled $B$. tequilensis resulted in incorporation of ${ }^{15} \mathrm{~N}$ into the isotopomers of pheophytin. The relative abundance of the isotopomers $\mathrm{m} / z 872.57$, $873.57,874.57,875.57,876.57$ increase by $16,48,106,128$ and $200 \%$ respectively $(\mathrm{p}<0.08 ; \mathrm{p}<0.02 ; \mathrm{p}<0.05 ; \mathrm{p}<0.01$ and $\mathrm{p}<0.003$, respectively for $m / z 871.57,872.57,873.57,874.57$ and 875.57, comparing ${ }^{14} \mathrm{~N}$ and ${ }^{15} \mathrm{~N}$-labeled B. tequilensis groups, Fig. $4 \mathrm{D}$ and inset $4 \mathrm{~B}$ and $4 \mathrm{C}$ ). The ${ }^{15} \mathrm{~N}$ uptake to form the isotopomer $\mathrm{m} / \mathrm{z}$ 876.57 pheophytin was notably greater, than that of unlabeled leaves, attesting to the incorporation of ${ }^{15} \mathrm{~N}$ atoms into the tetrapyrrole ring of the pheophytin molecule.

\section{Experiment 2}

Biomass increases in plants. In this experiment we treated plants with live or heat-killed ${ }^{15} \mathrm{~N}$-labeled Bacillus $\left(121^{\circ} \mathrm{C}, 10 \mathrm{~min}\right)$; and

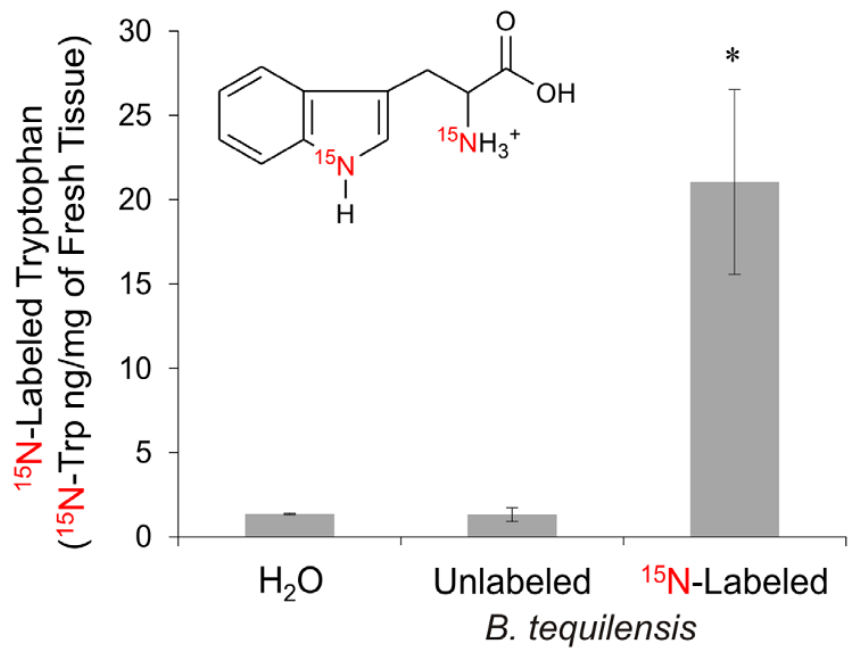

Figure $2 \mid$ Quantification of ${ }^{15} \mathrm{~N}$-Trp in foliar tissue of $A$. tequilana using HPLC-MS/MS. The sample groups analyzed were $\mathrm{H}_{2} \mathrm{O}$ treated, unlabeled B. tequilensis $\left({ }^{14} \mathrm{~N}\right.$-Bteq) and ${ }^{15} \mathrm{~N}$-labeled B. tequilensis $\left({ }^{15} \mathrm{~N}\right.$-Bteq) . Nitrogen content was calculated as the quantity of ${ }^{15} \mathrm{~N}$-Trp (ng/mg). Data are the mean values \pm standard error of the mean from three independent experiments. $\left({ }^{*}\right)^{15} \mathrm{~N}$-labeled $B$. tequilensis data are significantly different when compared with the $\mathrm{H}_{2} \mathrm{O}$ and unlabeled $B$. tequilensis groups $(\mathrm{p}<0.05)$. For multiple comparisons, t-test was applied. 


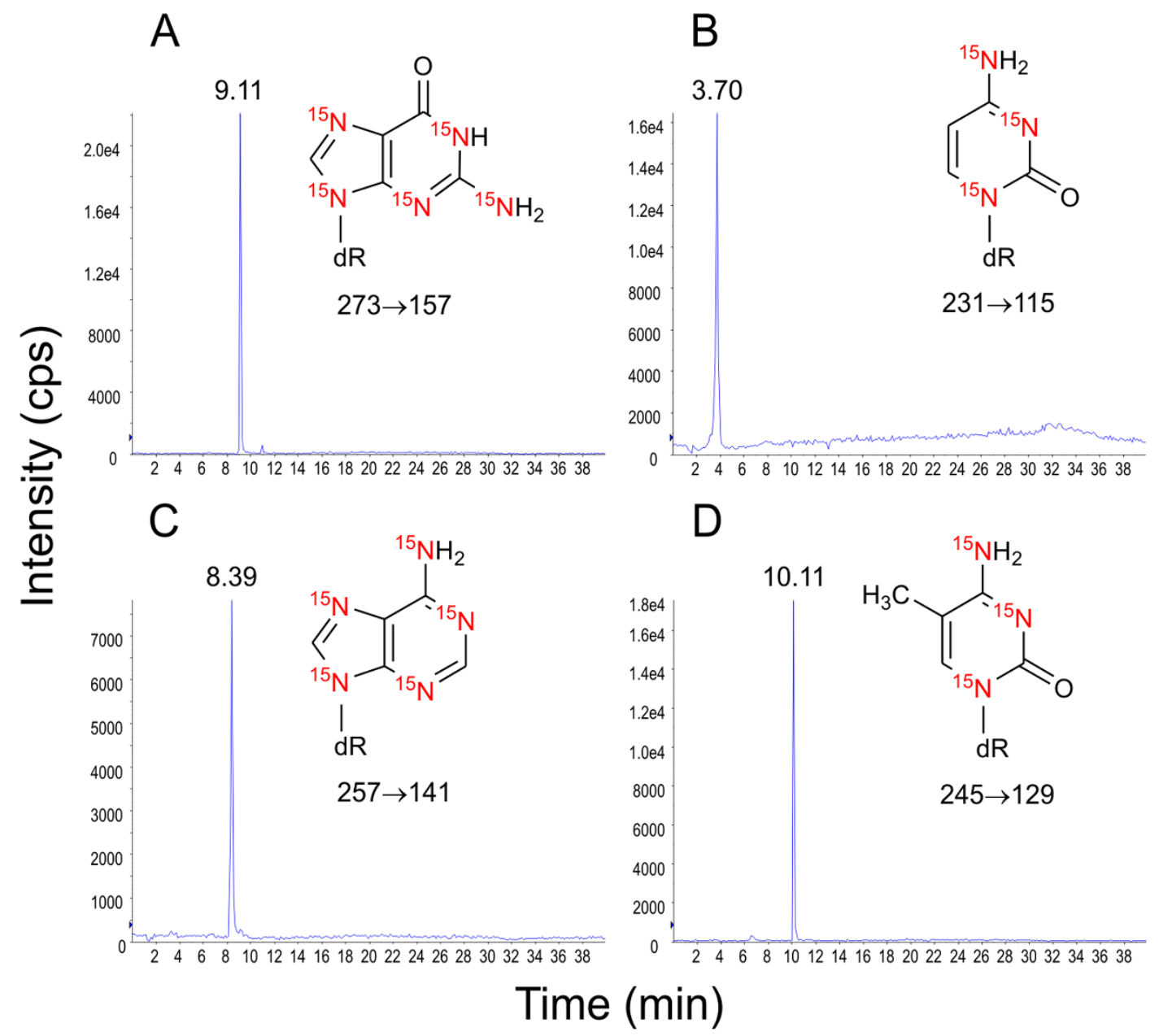

Figure 3 HPLC-MS/MS analysis of ${ }^{15} \mathrm{~N}$-labeled 2 '-deoxynucleosides from $A$. tequilana supplemented with ${ }^{15} \mathrm{~N}$-labeled B. tequilensis. $2^{\prime}$ Deoxynucleosides were detected by the loss of the 2-deoxyribose moiety: ${ }^{15} \mathrm{~N}_{5}-\mathrm{dG}, m / z 273 \rightarrow 157(\mathrm{~A}),{ }^{15} \mathrm{~N}_{3}-\mathrm{dC}, m / z 231 \rightarrow 115(\mathrm{~B}),{ }^{15} \mathrm{~N}_{5}-\mathrm{dA}, m / z 257 \rightarrow 141$ (C) and ${ }^{15} \mathrm{~N}_{2}$-dT, $m / z 245 \rightarrow 129$ (D).

with MMN solution (see methods), non-endophytic E. coli (not labeled) and water as controls. Biomass measurements after two months of treatment showed that the greatest biomass increase was seen in plants treated with living $B$. tequilensis, where mean biomass increase was $1.63 \pm 0.28 \mathrm{~g}$ (mean \pm standard deviation). Plants treated with heat-killed $B$. tequilensis or mineral nutrient solution $(\mathrm{MMN})$ showed biomass increases of $0.83 \pm 0.16 \mathrm{~g}$ for heat-killed B. tequilensis; and $0.52 \pm 0.34 \mathrm{~g}$ for MMN. Plants treated with non-endophytic Escherichia coli showed a biomass increase of $0.71 \pm 0.14 \mathrm{~g}$. Plants treated only with water showed the least biomass increase $(0.15 \pm 0.05 \mathrm{~g})$.

Comparison of ${ }^{15} \mathrm{~N}$ absorption from living verses dead B. tequilensis. To evaluate the extent to which ${ }^{15} \mathrm{~N}$ was moving into plant tissues after the death of bacteria in soil or through endophytic colonization, we included in the experiment living and heat-killed B. tequilensis that had been labeled with ${ }^{15} \mathrm{~N}$. On analysis we found that incorporation of ${ }^{15} \mathrm{~N}$ into nucleosides, $2^{\prime}$-deoxycytidine $\left({ }^{15} \mathrm{~N}_{3}\right.$ $\mathrm{dC})$ and $2^{\prime}$-deoxyadenosine $\left({ }^{15} \mathrm{~N}_{5}-\mathrm{dA}\right)$ was significantly greater $(\mathrm{p}<0.05)$ in plants treated with live Bacillus (a.u.: ${ }^{15} \mathrm{~N}_{3}-\mathrm{dC} 1.13 \times$ $10^{2} \pm 13.93 ;{ }^{15} \mathrm{~N}_{5}$-dA $\left.4.50 \times 10^{1} \pm 9.05\right)$ than plants treated with the heat-killed Bacillus (a.u.: ${ }^{15} \mathrm{~N}_{3}$-dC $3.40 \times 10^{1} \pm 26.51 ;{ }^{15} \mathrm{~N}_{5}$-dA 1.10 $\left.\times 10^{1} \pm 6.83\right)^{28-32}$.

\section{Discussion}

The assimilation of ${ }^{15} \mathrm{~N}_{2}$ gas into tissues of Agave seedlings is indicative of the presence of nitrogen-fixing microorganisms within seedling tissues. From seedlings, seeds and bulbillos, we consistently isolated Bacillus tequilensis; however, plants may also have contained other non-cultured bacteria that could have been responsible for $\mathrm{N}$ fixation in plant tissues. We do not consider B. tequilensis to be responsible for $\mathrm{N}_{2}$ fixation in plant tissues; however, because of its ease of culturing and its endophytic nature, we employed B. tequilensis in experiments to evaluate the hypothesis that nitrogenous nutrients may flow from bacterial endophyte populations to plants.

We labeled proteins and nucleic acids of $B$. tequilensis with ${ }^{15} \mathrm{~N}$; then inoculated plants with suspensions of bacteria. Using these bacteria we conducted two experiments. In the first experiment we watered plants weekly with a $4 \mathrm{~mL}$ suspension of $80 \bullet 10^{6} \mathrm{CFU} \mathrm{mL}^{-1}$ of ${ }^{15} \mathrm{~N}$-labeled Bacillus for a six-month period. Our results show that plants incubated with the bacterial endophyte came to contain $\mathrm{N}$ that was originally contained within the bacterium. Detection of ${ }^{15} \mathrm{~N}-$ labeled tryptophan and 2 -deoxynucleosides suggests that ${ }^{15} \mathrm{~N}$ labeled bacterial endophytes enter into or otherwise associate with plant tissues. Because both bacteria and plants possess tryptophan and 2 -deoxynucleosides, with this data alone we cannot evaluate transfer of nitrogen from bacterium to plant. However, we were able to detect the ${ }^{15} \mathrm{~N}$ in pheophytin $a$, a molecule derived from plant chlorophylls. Because chlorophyll is unique to the plant cells, the presence of the ${ }^{15} \mathrm{~N}$ label there is a definitive confirmation of transference of $\mathrm{N}$ from bacterium to plant tissues.

A second experiment was conducted to evaluate whether soil absorption from dead bacteria could account for some ${ }^{15} \mathrm{~N}$ movement into plant tissues, we developed an experiment in which we 


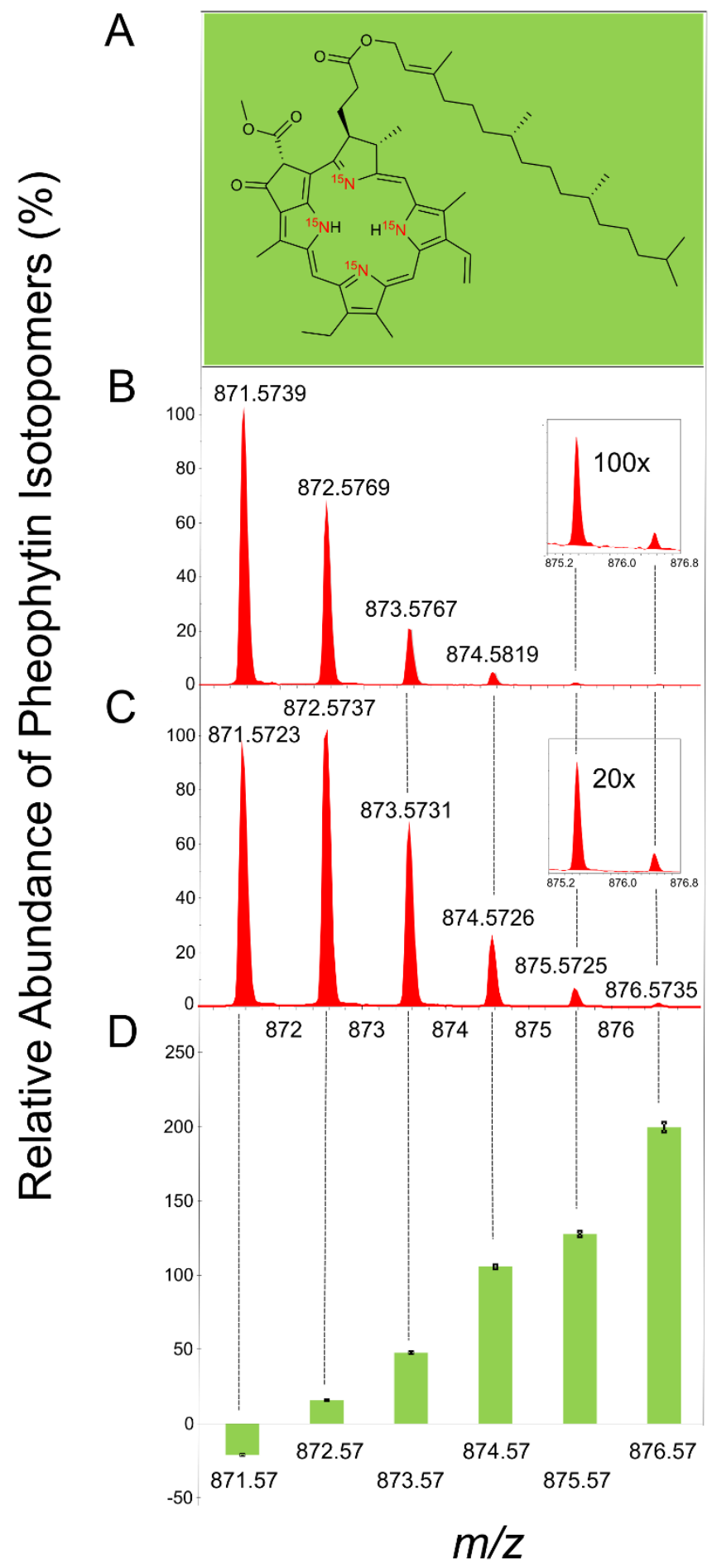

Figure 4 Relative abundance of pheophytin isotopomers from $A$. tequilensis. (A) Chemical structure; (B) Percentage increase of pheophytin isotopomers calculated from plants supplemented with unlabeled $B$. tequilensis (C) and with ${ }^{15} \mathrm{~N}$-labeled B. tequilensis (D). The data points shown are the mean values \pm standard error of the mean from three independent experiments. $\mathrm{p}<0.08 ; \mathrm{p}<0.02 ; \mathrm{p}<0.05 ; \mathrm{p}<0.01$ and $\mathrm{p}<0.003$, respectively for $m / z 871.57,872.57,873.57,874.57$ and 875.57, comparing ${ }^{14} \mathrm{~N}$ and ${ }^{15} \mathrm{~N}$-labeled B. tequilensis groups.

treated plants with live or heat-killed ${ }^{15} \mathrm{~N}$-labeled bacteria $\left(121^{\circ} \mathrm{C}\right.$, $10 \mathrm{~min})$; and with $\mathrm{MMN}$ solution, non-endophytic E. coli (not labeled) and water as controls. Plants were watered weekly for a two-month period using $4 \mathrm{~mL}$ of bacterial suspension at a concentration of $80 \bullet 10^{6} \mathrm{CFU} \mathrm{mL}^{-1}$ or $\mathrm{MMN}$ solution. In this experiment we found significantly more incorporation of ${ }^{15} \mathrm{~N}$ into 2 -deoxynucleosides in plants treated with live Bacillus than in plants treated with heat-killed Bacillus. We further evaluated the growth of these plants compared with those treated with water, $E$. coli or mineral nutrient solution. The amount of total acquired biomass was almost double in plants treated with living Bacillus than in plants treated with heat-killed Bacillus and E. coli; and more than 3.3 times that seen in plants treated with mineral solution. Enhanced growth of plants, and incorporation of the ${ }^{15} \mathrm{~N}$ label into plants treated with living ${ }^{15} \mathrm{~N}$-labeled bacteria are results that are consistent with a scenario where $\mathrm{N}$ is transferred to plants from bacteria within tissues of plants rather than being absorbed primarily from dead bacteria in the soil. The fact that non-endophytic E. coli-treated plants demonstrated a biomass increase half that of living endophyte cultures suggests that efficient movement of $\mathrm{N}$ from bacteria to plants is a function of living, plant-colonizing, endophytic bacteria. The results of our experiments suggest that some nitrogen may come from decomposition of microbes in the soil. Decomposition of microbes in the soil could explain biomass increases in plants treated with heatkilled B. tequilensis and non-endophytic E. coli.

Microscopic observations of plant roots treated with the living Bacillus and stained using a reactive oxygen probe showed that degrading bacterial cells were associated with reactive oxygen and were often internalized into plant roots. Our observations are similar to those of Paungfoo-Lonhienne et al. ${ }^{3}$, where microbes were shown to enter into root cells of tomato and Arabidopsis where they were degraded. The involvement of reactive oxygen in procurement of organic nutrients from bacteria is consistent with 'oxidative nitrogen scavenging', where reactive oxygen and proteases may be involved in nutrient extraction from bacteria ${ }^{4,33}$. We did not visualize bacteria or their degradation in shoot tissues; however, this is likely due to failure of the aqueous stains to penetrate into the shoot, rather than their absence from shoots.

In a recent study that evaluated the contribution of organic $\mathrm{N}$ in wheat from direct microorganism consumption against nitrate, $L$-alanine and $L$-tetraalanine absorption, it was found that plants absorbed nutrients through endocytosis of soil microbes, but the $\mathrm{N}$ obtained through this process was up to two orders of magnitude slower than other forms of organic and inorganic $\mathrm{N}$ in the soil $^{5}$. Our study examining nutrient transfer from $B$. tequilensis to Agave suggests a process where endophytic bacterial degradation may supply $\mathrm{N}$ for plant growth; however, this mechanism may not be rapid and it could depend on occurrence of $\mathrm{N}$ deficiency or other nutrient depletion in soils. Our initial experiment to evaluate movement of ${ }^{15} \mathrm{~N}$ into plant molecules lasted six months. We do not know the minimum amount of time or precise plant growth conditions needed to see movement of $\mathrm{N}$ from bacterial endophytes to host plants. We propose that efficiency of this mode of nutrition depends on the particular host and microbe association. Agave tequilana is a desert plant adapted to growth under low $\mathrm{N}$ soil conditions and B. tequilensis is a native endophytic microbe of that plant. Internal colonization of plant tissues may increase the probability of transference of nutrients from endophytes to host plants. In this respect endophytic microbes that fix $\mathrm{N}$ may represent a nutritional resource that may be tapped into when soil $\mathrm{N}$ is limiting. Equally important to plants could be $\mathrm{N}$ derived from soil microbes that grow and obtain nutrients in the soil then colonize growing plants where they may be degraded. Whether $\mathrm{N}$ derived from microbes is a significant source of $\mathrm{N}$ for plants is a question that requires additional investigation. While our experiments on $\mathrm{N}$ transfer from endophyte to host in Agave are not exhaustive, they do provide further evidence that plants may obtain $\mathrm{N}$ through degradation of symbiotic microbes ${ }^{3-5,33}$. 


\section{Methods}

Plant materials. For experiments we used one-yr-old seeds and asexual plantlets (bulbillos) derived from plants of Agave tequilana Weber that were originally collected on an A. tequilana plantation near Atotonilco el Alto, Jalisco, Mexico at coordinates $20^{\circ} 34^{\prime} 22.71^{\prime \prime} \mathrm{N}, 102^{\circ} 32^{\prime} 00.85,1900$ masl.

${ }^{15} \mathrm{~N}_{2}$ gas assimilation experiment with seedlings. An experiment was conducted to evaluate whether endophytic microbes fix nitrogen within intact plant tissues. In this experiment seeds were surface disinfected in 3\% sodium hypochlorite for 20 min with constant agitation to remove external bacteria, then rinsed three times using sterile water. Five seeds were plated onto $0.7 \%$ agarose media in each of eight Petri dishes. Four Petri plates were placed in a 1-liter gas chamber in which the air was enriched with $33 \mathrm{~mL}$ of ${ }^{15} \mathrm{~N}_{2}$ gas. The other four Petri dishes were placed in a chamber in which the air was not enriched with ${ }^{15} \mathrm{~N}_{2}$. Both chambers were placed under fluorescent lighting with alternating light/dark periods $(10 \mathrm{hr} / 14 \mathrm{hr})$ at laboratory ambient temperature for 21 days. After incubation shoots were excised from roots, washed to remove any superficial bacteria, then dried for $14 \mathrm{hr}$ in an oven at $60^{\circ} \mathrm{C}$. All shoots from a plate were combined to ensure sufficient material for analysis. For massspectroscopic ${ }^{14} \mathrm{~N} /{ }^{15} \mathrm{~N}$ ratio analysis, we sent $0.9-1.0 \mathrm{~g}$ of dried shoot material to the Stable Isotope/Soil Biology Laboratory at the Odum School of Ecology at the University of Georgia, Athens, USA.

Isolation of bacteria from A. tequilana seeds. Seeds were surface sterilized to remove epiphytic microbes. In this process seeds were immersed in a $3 \%$ hypochlorite solution for twenty minutes with constant agitation. The seeds were then rinsed with sterile distilled water and placed in $85 \%$ ethyl alcohol for ten minutes, followed by three rinses with sterile distilled water. To confirm the disinfection process, aliquots of the sterile water used in the final rinse were plated in tryptic soy agar (TSA; Difco, Sparks, MD, USA) and incubated at $28^{\circ} \mathrm{C}$ for 15 days, after which plates were examined for the presence of microorganism growth. To isolate bacteria, we used two procedures: 1) 30 sterilized seeds were placed onto $15 \mathrm{~cm}$ diameter Petri plates containing potato dextrose agar (PDA, Difco, Sparks, MD); and 2) Ten seeds were ground with $5 \mathrm{~mL}$ of aqueous solution $(0.9 \% \mathrm{NaCl})$ using a sterile mortar and pestle and the seed extract was plated on TSA plates with different volumes (50 to 350 microliters per plate). All plates were incubated at $28^{\circ} \mathrm{C}$ for seven days until creamcolored colonies appeared.

Identification of bacterium by $16 \mathrm{~S}$ rRNA and sequencing. For bacterial identification, 980 base pairs of the $16 \mathrm{~S}$ rDNA region were sequenced ${ }^{24}$. Sequences were compared to sequences available in the NCBI GenBank database to identify the closest matches. We submitted a representative sequence to NCBI (GenBank accession number KF792125).

\section{Experiment 1}

Plant growth conditions. To reactivate bulbillos of $A$. tequilana collected from the field, plants were grown in sterile soil in a growth chamber at $27^{\circ} \mathrm{C}$ with $50 \%$ humidity under $14 \mathrm{~h}$ light and $10 \mathrm{~h}$ dark photoperiods and lamp intensities of $80 \mathrm{Watts} / \mathrm{m}^{2}$ for three weeks. Then plantlets were rinsed with sterile water to eliminate organic soil on roots and transferred immediately to $\mathrm{N}$-free sand ( $30 \mathrm{~g}$ per glass bottle) for another three weeks maintained under the same conditions.

Visualization of bacterial oxidation in A. tequilana seedlings and bulbillos. To visualize bacterial oxidation in plant tissues, we stained seedlings and bulbillos with $\mathrm{DAB} /$ horseradish peroxidase for a $6-12 \mathrm{~h}$ period. We then excised seedling roots and shoots and placed them on a slide containing $0.1 \%$ aqueous toluidine blue. The $\mathrm{DAB} /$ peroxidase probe was prepared with a $5 \mathrm{~mL}$ solution of $100 \mathrm{mM}$ potassium phosphate buffer, $\mathrm{pH}$ 6.9, $2.5 \mathrm{mM}$ diaminobenzidine tetrachloride and 5purpurogallin units/mL of horseradish peroxidase (Type VI, Sigma, St. Louis, MO, USA $)^{25,33}$. Slides were examined using bright field microscopy on a Zeiss Axioskope ${ }^{\circledR}$ with a Spot Insight ${ }^{\mathrm{TM}} 4$ megapixel digital camera.

Bacterial growth and $\left[{ }^{15} \mathrm{~N}\right]$-labeling. Bacillus tequilensis was grown and maintained in TSA. To evaluate transferral of organic $\mathrm{N}$ from bacteria to plants under limited nutrient conditions, we labeled $B$. tequilensis using ${ }^{14} \mathrm{NH}_{4} \mathrm{Cl}$ or ${ }^{15} \mathrm{NH}_{4} \mathrm{Cl}$ as the sole $\mathrm{N}$ sources in minimal medium M9 and incubated for $18 \mathrm{~h}$ at $200 \mathrm{rpm}$. All bacteria cultured with ${ }^{15} \mathrm{~N}$ contained nucleic acids labeled with isotopic N (Supplementary Fig. S8). ${ }^{15} \mathrm{~N}$-Labeling of Bacillus tequilensis was confirmed by reversed phase HPLC-MS analysis of DNA bases (Supplementary Fig. S8). The HPLC-MS results showed complete ${ }^{15} \mathrm{~N}$-labeling of nitrogen atoms of purine and pyrimidine bases through detection of ${ }^{15} \mathrm{~N}$-labeled guanine at $m / z 157$ (Supplementary Fig. S8B), ${ }^{15} \mathrm{~N}$-labeled cytosine at $m / z 115$ (Supplementary Fig. S8C), ${ }^{15} \mathrm{~N}$-labeled adenine at $\mathrm{m} / z 157$ (Supplementary Fig. S8D) and ${ }^{15} \mathrm{~N}$-labeled thymine at $\mathrm{m} / z 129$ (Supplementary Fig. $\mathrm{S} 8 \mathrm{E})$. Agave plantlets growing in sterile sand $\left(\mathrm{SiO}_{2}\right)$ were inoculated with ${ }^{15} \mathrm{~N}$-labeled B. tequilensis $\left({ }^{15} \mathrm{~N}\right.$-Bteq) or unlabeled B. tequilensis $\left({ }^{14} \mathrm{~N}\right.$-Bteq). Four $\mathrm{mL}$ of bacteria adjusted to 1 at $\mathrm{OD}_{600}$ (equivalent to $80 \bullet 10^{6} \mathrm{CFU} \mathrm{mL}^{-1}$ ) were administered to plants every week for six months. Controls included plants treated with $\mathrm{H}_{2} \mathrm{O},{ }^{14} \mathrm{~N}$ and ${ }^{15} \mathrm{~N}$ MMN solution.

Plant treatments and inoculation with bacteria. The plants used in this study were treated with $4 \mathrm{~mL}$ of: 1) water, 2) unlabeled MMN medium containing $\mathrm{NH}_{4} \mathrm{Cl}$ $\left({ }^{14} \mathrm{NH}_{4} \mathrm{Cl}\right)$, 3) labeled MMN medium containing ${ }^{15} \mathrm{NH}_{4} \mathrm{Cl}\left({ }^{15} \mathrm{NH}_{4} \mathrm{Cl}\right)$, 4) unlabeled bacteria suspension $\left({ }^{14} \mathrm{~N}-\right.$ Bteq $)$ or 5.) labeled bacteria suspension $\left({ }^{15} \mathrm{~N}-\mathrm{Bteq}\right) . \mathrm{NH}_{4} \mathrm{Cl}$ medium or ${ }^{15} \mathrm{NH}_{4} \mathrm{Cl}$ medium was prepared with $0.5 \mathrm{~g} / \mathrm{L}^{14} \mathrm{NH}_{4} \mathrm{Cl}$ or ${ }^{15} \mathrm{NH}_{4} \mathrm{Cl}$ and $0.05 \mathrm{~g} / \mathrm{L} \mathrm{CaCl} 2,0.025 \mathrm{~g} / \mathrm{L} \mathrm{NaCl}, 0.05 \mathrm{~g} / \mathrm{L} \mathrm{KH}_{2} \mathrm{PO}_{4}, 0.15 \mathrm{~g} / \mathrm{L} \mathrm{MgSO}_{4} .7 \mathrm{H}_{2} \mathrm{O}, 1 \mathrm{mg} / \mathrm{L}$ $\mathrm{FeCl}_{3} \cdot 6 \mathrm{H}_{2} \mathrm{O}, 5 \mathrm{~g} / \mathrm{L}$ glucose monohydrate and $10 \mathrm{~mL}$ of trace elements solution. Trace element solution contained $3.728 \mathrm{~g} / \mathrm{L} \mathrm{KCl}, 1.546 \mathrm{~g} / \mathrm{L} \mathrm{H}_{3} \mathrm{BO}_{3}, 0.845 \mathrm{~g} / \mathrm{L} \mathrm{MnSO} \cdot \mathrm{H}_{2} \mathrm{O}$, $0.05 \mathrm{~g} / \mathrm{L} \mathrm{ZnSO}_{4} .7 \mathrm{H}_{2} \mathrm{O}, 0.0125 \mathrm{~g} / \mathrm{L} \mathrm{CuSO}_{4}$ and $0.05 \mathrm{~g} / \mathrm{L}\left(\mathrm{NH}_{4}\right)_{6} \mathrm{Mo}_{7} \mathrm{O}_{24} \cdot 4 \mathrm{H}_{2} \mathrm{O}$. Bacillus tequilensis cells were grown for $18 \mathrm{~h}$ at $37^{\circ} \mathrm{C}$ in minimal medium with ${ }^{14} \mathrm{~N}$ and ${ }^{15} \mathrm{~N}$ as $\mathrm{NH}_{4} \mathrm{Cl}$, pelleted by centrifugation $\left(5,000 \times\right.$ gravity, $\left.20 \mathrm{~min}, 4^{\circ} \mathrm{C}\right)$, and washed three times in sterilized glucose solution $(0.08 \%)$. Four-mL of labeled or unlabeled bacterial cells (see above section 'Bacterial growth and ${ }^{15} \mathrm{~N}$ labeling') were adjusted to 1 at $\mathrm{OD}_{600}$ (equivalent to $80 \bullet 10^{6} \mathrm{CFU} \mathrm{mL} \mathrm{m}^{-1}$ ) and used to inoculate each plant of $A$. tequilana maintained in sterile sand ( $30 \mathrm{~g} / \mathrm{dry} \mathrm{wt})$. Additional treatments included plants watered with a mineral solution (50\% MMN) supplemented with isotopic or non-isotopic $\mathrm{NH}_{4} \mathrm{Cl}$; and plants watered with sterilized distilled water. The plants were watered once a week with $4 \mathrm{~mL}$ of each treatment during a six-month period. All plants were approximately $10-12 \mathrm{~cm}$ in height with 1 or 2 open leaves. Plants were grown in glass bottles in a growth chamber at $27^{\circ} \mathrm{C}$ day/night temperature, $14 \mathrm{~h}$ photoperiod.

Analysis of plant for ${ }^{15} \mathrm{~N}$ incorporation. The central leaf 'cogollo' and new leaves of B. tequilensis-inoculated plants were taken and the presence of ${ }^{15} \mathrm{~N}$-labeled tryptophan $\left({ }^{15} \mathrm{~N}\right.$-Trp) was quantified by High-Performance Liquid Chromatography coupled to Mass Spectrometry in tandem (HPLC-MS/MS). To reduce the chances that the ${ }^{15} \mathrm{~N}$-labeled tryptophan was from the living bacterium rather than the host plant, the extraction was carried out seven days after inoculation with ${ }^{15} \mathrm{~N}$-labeled bacteria. The detection and quantification of ${ }^{15} \mathrm{~N}$-Trp in A. tequilana was performed by HPLC-MS/MS, in the Selected Reaction Monitoring (SRM) mode $(m / z 207 \rightarrow 189)$ (Supplementary Fig. S2-S4). The concentration of ${ }^{15} \mathrm{~N}$-Trp was determined in the samples through a calibration curve with standard solution of ${ }^{15} \mathrm{~N}$-Trp and melatonin $\mathrm{D}_{3}$-labeled $\left(\mathrm{Mel}-\mathrm{D}_{3}\right)$, as internal standard (Supplementary Fig. S5-S7) ${ }^{28}$.

Protein extraction from A. tequilana. See Supplementary Note 1.

HPLC-MS/MS analysis of tryptophan. See Supplementary Note 2.

Extraction of pheophytin from A. tequilana. To confirm that $\mathrm{N}$ transferred from microbes to plant tissue, an analysis in high-resolution mass spectrometry was carried out to evaluate the relative abundance of isotopomers of pheophytin (Fig. 4). Pheophytin is a magnesium-free derivative of chlorophyll, which has advantages over chlorophylls for isotopic analysis because of its stability, simpler mass spectra and better ionization characteristics. Pheophytin was extracted following the method of Perkins and Roberts ${ }^{26,27}$, with some modifications. Briefly, $0.5 \mathrm{~g}$ fresh leaves were frozen in liquid $\mathrm{N}_{2}$ and ground to a fine powder using mortar and pestle. For pheophytin extraction equal volumes of $85 \%$ acetone in $1 \mathrm{~mL}$ water, and ethyl ether were added and centrifuged at 10,000 rpm for $10 \mathrm{~min}$. The ether phase was collected and the procedure was repeated two times. Chlorophyll was converted to pheophytin by adding $10 \mu \mathrm{L}$ diluted $6 \mathrm{M} \mathrm{HCl}$ to the ether extract. The excess of $\mathrm{HCl}$ was removed by adding $500 \mu \mathrm{L}$ of water and centrifuging at 10,000 rpm for $10 \mathrm{~min}$, three times. The ether phase was collected, dried and prepared for HPLC/MS analysis by adding methanol to obtain a final sample concentration of $1 \mathrm{mg} / \mathrm{mL}$.

HPLC/MS analysis of pheophytin. Pheophytin samples were analyzed using a MicroTOFQ-II mass spectrometer (Bruker) coupled to a Shimadzu HPLC system (Tokyo, Japan) with two pumps LC-20AD, automatic injector SIL-20A, column oven CTO-20A, UV detector SPD-20A and controller CBM-10A. A column Phenomenex Luna $5 \mu \mathrm{m}$ (PFP2 $150 \times 2 \mathrm{~mm}, 100 \mathrm{~A}$ particle size) was used and chromatography was performed with a flux of $200 \mu \mathrm{L} / \mathrm{min}$ using acetonitrile: $\mathrm{H}_{2} \mathrm{O}(+0.1 \%$ formic acid) as mobile phase in a gradient of 0 to $5 \mathrm{~min} 60 \%$ of acetonitrile, from 5 to $30 \mathrm{~min}$ 60 to $100 \%$ of acetonitrile. The column oven was kept in $40^{\circ} \mathrm{C}$, UV detector was recorded at 400 and $600 \mathrm{~nm}$. The mass spectrophotometer was operating in electrospray positive mode, with a nebulization and drying gas at $4 \mathrm{Bar}$ and $8 \mathrm{~L} / \mathrm{min}$, respectively. Capillar voltage was set to $4500 \mathrm{~V}$ and drying temperature in $200^{\circ} \mathrm{C}$. Collision cell and quadrupole energy were set to $20 \mathrm{eV}$ and $10 \mathrm{eV}$, respectively. The molecular formula of pheophytin $a$ is $\mathrm{C}_{55} \mathrm{H}_{74} \mathrm{~N}_{4} \mathrm{O}_{5}$ and the base peak was detected at $[\mathrm{M}+\mathrm{H}]^{+}=872.5731$.

Extraction of DNA from A. tequilana. DNA extraction from A. tequilana leaves was made after six months of treatments as described above. Freshly collected leaves $(1 \mathrm{~g})$ were ground to powder in liquid nitrogen and DNA was extracted with $1 \mathrm{~mL}$ of $50 \mathrm{mM}$ extraction buffer ( $\mathrm{pH} 8.0$ ) containing $2 \% \mathrm{CTAB}(\mathrm{p} / \mathrm{v}), 1.4 \mathrm{M} \mathrm{NaCl}, 100 \mathrm{mM}$ Tris-HCl, $20 \mathrm{mM}$ EDTA and $0.2 \%$ (v/v) $\beta$-mercaptoethanol. The solution was kept at $60^{\circ} \mathrm{C}, 800 \times$ r.p.m for 30 minutes. Following, eppendorf tubes were left at room temperature and $500 \mu \mathrm{l}$ of chloroform: isoamyl alcohol $\left(24: 1 \mathrm{v} / \mathrm{v},-20^{\circ} \mathrm{C}\right)$ was added. The solution was maintained under agitation $(10$ minutes, $300 \times$ r.p.m), centrifuged $(12,000 \times$ r.p.m, $10 \mathrm{~min}$, room temperature) and the organic phase discarded. RNAse A was added (in Tris $50 \mathrm{mM}, \mathrm{pH}$ 8.0, final concentration: $0.1 \mathrm{mg}$ / $\mathrm{mL}$ ) and the solution was incubated at $37^{\circ} \mathrm{C}$ for 30 minutes and agitated at $300 \times$ r.p.m. Following this, isopropyl alcohol $\left(-20^{\circ} \mathrm{C}\right)$ was added and the mixture was gently shaken and centrifuged $(20$ minute, $13,000 \times$ r.p.m). This procedure was repeated twice. The mixture was washed with $60 \%$ isopropyl alcohol $\left(-20^{\circ} \mathrm{C}\right)$ twice, centrifuged $(5 \mathrm{~min}, 3,000 \times$ r.p.m) and supernatant discarded. The DNA pellet was washed twice with $500 \mu \mathrm{L}$ of $70 \%$ ethanol $\left(-20^{\circ} \mathrm{C}\right)$, centrifuged, dried on speed vac 
and re-suspended in $0.1 \mathrm{mM}$ desferroxamine. DNA concentration was measured spectrophotometrically at $260 \mathrm{~nm}$.

Enzymatic hydrolysis of DNA from A. tequilana. See Supplementary Note 3.

HPLC-MS/MS analysis of DNA from A. tequilana. HPLC-MS/MS analysis was performed using an Agilent HPLC (1200 series, Agilent Waldbronn, Germany) coupled to a linear ion trap mass spectrometer (4000 QTRAP mass spectrometer, Applied Biosystems, Foster City, CA, USA) with electrospray ionization source. The column oven and auto sampler temperatures were set at $25^{\circ} \mathrm{C}$ and $4^{\circ} \mathrm{C}$, respectively. For the separation, a reversed phase column was used [(C18(2)-HST Luna, Phenomenex, $100 \mathrm{~mm} \times 2.0 \mathrm{~mm}, 2.5 \mu \mathrm{m}$ particle size)]. Flow rate was set at $0.2 \mathrm{~mL} /$ min. Gradient elution was carried out with $0.1 \%$ formic acid (A) and acetonitrile: $0.1 \%$ formic acid $(8: 2, \mathrm{v} / \mathrm{v})$ (B). The separation was conducted with 0 to $40 \% \mathrm{~B}$ during the first 15 minutes, $40 \%$ B for 10 minutes, $40 \%$ to $0 \%$ B for 1 minute and $0 \%$ B for 35 minutes. MS/MS spectrometry analysis was performed in positive ionization mode and using SRM mode for each $2^{\prime}$-deoxynucleoside that corresponded to the loss of 2 deoxyribose moiety: $2^{\prime}$-deoxyguanosine $\left({ }^{15} \mathrm{~N}_{5}-\mathrm{dG}, m / z 273 \rightarrow 157\right), 2^{\prime}$-deoxycytidine $\left({ }^{15} \mathrm{~N}_{3}\right.$-dC, $\left.m / z 231 \rightarrow 115\right), 2^{\prime}$-deoxyadenosine $\left({ }^{15} \mathrm{~N}_{5}-\mathrm{dA}, \mathrm{m} / z 257 \rightarrow 141\right), 2^{\prime}$ deoxythymidine $\left({ }^{15} \mathrm{~N}_{2}-\mathrm{dT}, m / z 245 \rightarrow 129\right)$, 5-methyl- $2^{\prime}$-deoxycytidine $\left({ }^{15} \mathrm{~N}_{3}\right.$ - MedC, $m / z 245 \rightarrow 129)$ and $N^{\prime}$-methyl-2' -deoxyadenosine $\left({ }^{15} \mathrm{~N}_{5}\right.$-MedA, $\left.m / z 271 \rightarrow 155\right)$ (Fig. 3 and Supplementary Fig. S9 to 11$)^{29-32}$. Mass spectrometry analyses were performed with the following parameters: collision excitation potential, $10 \mathrm{~V}$; collision activated dissociation gas flow, medium; pause time, $5 \mathrm{~ms}$; dwell time, $300 \mathrm{~ms}$; curtain gas, $12 \mathrm{psi}$; ion source, $5500 \mathrm{~V}$; temperature, $650^{\circ} \mathrm{C}$; gas 1 and gas 2 , $40 \mathrm{psi}$; declustering potential, $31 \mathrm{~V}$ and entrance potential, $10 \mathrm{~V}$.

Analysis of ${ }^{15} \mathrm{~N}_{3}$-dC and ${ }^{15} \mathrm{~N}_{5}$-dA extracted from DNA of plants treated for two months with live or heat-killed ${ }^{15} \mathrm{~N}$-labeled bacteria was performed as described above.

HPLC-MS analysis of DNA from bacteria. See Supplementary Note 4.

\section{Experiment 2}

Plant mass accumulation study. To evaluate whether soil absorption from dead bacteria could account for some ${ }^{15} \mathrm{~N}$ movement into plant tissues, we developed an experiment in which we treated plants (six replicates per treatment) over a two month period with live or heat-killed ${ }^{15} \mathrm{~N}$-labeled B. tequilensis (heated to $121{ }^{\circ} \mathrm{C}, 10 \mathrm{~min}$ ), and with 50\% MMN solution, non-endophytic E. coli (not labeled) and water as controls. Bacteria were applied as described in Experiment 1 . To assess increase of ${ }^{15} \mathrm{~N}$ in leaves of Agave plants treated with ${ }^{15} \mathrm{~N}$-labeled bacteria, deoxynucleosides were extracted from leaves and 2 -deoxycytidine and $2{ }^{\prime}$-deoxyadenosine were measured. Measurements of plant mass with water-washed roots were made before and after two months of treatments. Biomass increase is the change in whole plant wet weight as a result of the treatments.

Statistical analyses. Statistical tests were performed with Origin (version 8.0) and GraphPad PRISM (version 5.0) programs. Significant differences were determined by t-test and one-way ANOVA (applying Dunnett's post-test) with the level of significance set at $\mathrm{P}<0.05$ for ${ }^{15} \mathrm{~N}$-Trp quantification, detection of nucleosides $\left({ }^{15} \mathrm{~N}_{3}\right.$ $\mathrm{dC}$ and ${ }^{15} \mathrm{~N}_{5}-\mathrm{dA}$ ) and biomass increase, respectively.

1. James, E. K. Nitrogen fixation in endophytic and associative symbiosis. Field Crop Res. 65, 197-209 (2000).

2. Reinhold-Hurek, B. \& Hurek, T. Living inside plants: bacterial endophytes. Curr. Opin. Plant Biol. 4, 435-443 (2011).

3. Paungfoo-Lonhienne, C. et al. Turning the Table: Plants Consume Microbes as a Source of Nutrients. PLoS ONE 5, e11915 (2010).

4. White, J. F. et al. A proposed mechanism for nitrogen acquisition by grass seedlings through oxidation of symbiotic bacteria. Symbiosis 57, 161-171 (2012).

5. Hill, P. W., Marsden, K. A. \& Jones, D. L. How significant to plant N nutrition is the direct consumption of soil microbes by roots? New Phytol. 199, 948-955 (2013).

6. Kaye, J. P. \& Hart, S. C. Competition for nitrogen between plants and soil microorganisms. Trends Ecol. Evol. 12, 139-143 (1997).

7. Lawlor, D. W., Lemaire, G. \& Gastal, F. [Nitrogen, plant growth and crop yield]. Plant Nitrogen. [Lea, P. J. \& Morot-Gaudry, J. F. (eds.)] [343-367](SpringerVerlag, Berlin 2001).

8. Cleveland, C. et al. Global patterns of terrestrial biological nitrogen (N) fixation in natural ecosystems. Global Biogeochem. Cycles 13, 623-645 (1999).

9. Herridge, D. F., Peoples, M. B. \& Boddey, R. M. Global inputs of biological nitrogen fixation in agricultural systems. Plant Soil 311, 1-18 (2008).

10. Mulvaney, L. R., Khan, S. A. \& Elisworth, T. R. Synthetic nitrogen fertilizers deplete soil nitrogen: A global dilema for sustainable cereal production. J. Environ. Qual. 38, 2295-2314 (2009).

11. Garnett, T., Conn, V. \& Kaiser, B. N. Root based approaches to improving nitrogen use efficiency in plants. Plant Cell Environ. 32, 1272-3040 (2009).

12. Smith, B. E. Nitrogenase reveals its inner secrets. Science 297, 1654-1700 (2002).

13. Paungfoo-Lonhienne, C. et al. Plants can use protein as a nitrogen source without assistance from other organisms. Proc. Natl. Acad. Sci. USA 105, 4524-4529 (2008).
14. Paungfoo-Lonhienne, C. et al. DNA is taken up by root hairs and pollen, and stimulates root and pollen tube growth. Plant Physiol. 153, 799-805 (2010).

15. Farrell, M. et al. Oligopeptides Represent a Preferred Source of Organic N Uptake: A Global Phenomenon? Ecosystems 16, 133-145 (2013).

16. Adlassnig, W. et al. Endocytotic uptake of nutrients in carnivorous plants. Plant J. 71, 303-313 (2012).

17. Behie, S. W., Zelisko, P. M. \& Bidochka, M. J. Endophytic insect-parasitic fungi translocate nitrogen directly from insects to plants. Science 336, 1576-1577 (2012).

18. Sturz, A. V., Christie, B. R. \& Nowak, J. Bacterial endophytes: potential role in developing sustainable systems of crop production. Crit. Rev. Plant Sci. 19, 1-30 (2000).

19. Anand, R. \& Chanway, C. P. Detection of GFP-labeled Paenibacillus polymyxa in auto-flourescing pine seedling tissues. Biol. Fertil. Soils 49, 111-118 (2013).

20. Gyaneshwar, P., James, E. K., Reddy, P. M. \& Ladha, J. K. Herbaspirillum colonization increase growth and nitrogen accumulation in aluminium tolerant rice varieties. New Phytol. 154,131-145 (2002).

21. Patten, C. L. \& Glick, B. R. Bacterial biosynthesis of indole-3-acetic acid. Can. J. Microb. 42, 207-22 (1996).

22. Baset Mia, M. A. \& Shamsuddin, Z. H. Nitrogen fixation and transportation by rhizobacteria: a scenario of rice and banana. Int. J. Botany. 6, 235-242 (2010).

23. White, J. F., Johnson, H., Torres, M. S. \& Irizarry, I. Nutritional endosymbiotic systems in plants: bacteria function like 'quasi-organelles' to convert atmospheric nitrogen into plant nutrients. J. Plant Pathol. Microb. 3, e104 (2012).

24. Baker, G. C., Smith, J. J. \& Cowan, D. A. Review and re-analysis of domain-specific 16 S primers. J. Microb. Methods 55, 541-555 (2003).

25. Munkres, K. D. Histochemical detection of superoxide radicals and hydrogen peroxide by Age-1 mutants of Neurospora. Fungal Genet. Newsletter 37, 24-25 (1990).

26. Kahn, M. L. et al. A mass spectroscopy method for measuring $15 \mathrm{~N}$ incorporation into pheophytin. Analyt. Biochem. 307, 219-225 (2002).

27. Perkins, H. J. \& Roberts, D. W. A. Purification of chlorophylls, pheophytins and pheophorbides for specific activity determinations. Biochim. Biophys. Acta 58, 486-498 (1962).

28. Almeida, E. A. et al. Synthesis of internal labeled standards of melatonin and its metabolite N1-acetyl-N2-formyl-5-methoxykynurenin for their quantification using an on-line liquid chromatography-electrospray tandem mass spectrometry system. J. Pineal Res 36, 64-71 (2004).

29. Hua, Y. et al. Comparison of negative and positive ion electrospray tandem mass spectrometry for the liquid chromatography tandem mass spectrometry analysis of oxidized deoxynucleosides. J. Am. Soc. Mass Spec. 12, 80-87 (2001).

30. Vanyushin, B. F. \& Ashapkin, V. V. DNA methylation in higher plants: past, present and future. Biochim. Biophys. Acta, Gene Regul. Mech. 1809, 360-368 (2011).

31. Barrientos, Y. E.,Wrobel, K. W., Torres, A. L., Corona, F. G. \& Wrobel, K. Application of reversed-phase high-performance liquid chromatography with fluorimetric detection for simultaneous assessment of global DNA and total RNA methylation in Lepidium sativum: effect of plant exposure to Cd(II) and $\mathrm{Se}(\mathrm{IV})$. Anal. Bioanal. Chem. 405, 2397-2404 (2013).

32. Charles, M. P. et al. N-6-methyideoxyadenosine, a nucleoside commonly found in prokaryotes, induces $\mathrm{C} 2 \mathrm{C} 12$ myogenic differentiation. Biochem. Biophys. Res. Commun. 314, 2476-482 (2004).

33. White, J. F. et al. Hydrogen peroxide staining to visualize bacterial infections of seedling root cells. Microsc. Res. Techniq. DOI:10.1002/jemt.22375 (2014).

\section{Acknowledgments}

The authors acknowledge the research funding institutions FAPESP (Fundação de Amparo à Pesquisa do Estado de São Paulo; No. 2012/12663-1, 2011/10048-5 and 2009/51850-9), CNPq (Conselho Nacional para o Desenvolvimento Científico e Tecnológico), CAPES (Coordenação de Aperfeiçoamento de Pessoal de Nível Superior), PRONEX/FINEP (Programa de Apoio aos Núcleos de Excelência), PRPUSP (Pro-Reitoria de Pesquisa da Universidade de São Paulo), Instituto do Milênio-Redoxoma (No. 420011/2005-6), INCT Redoxoma (FAPESP/CNPq/CAPES; No. 573530/2008-4), NAP Redoxoma (PRPUSP; No. 2011.1.9352.1.8), CEPID Redoxoma (FAPESP; No. 2013/07937-8), John Simon Guggenheim Memorial Foundation (P.D.M. Fellowship), the John E. and Christina C. Craighead Foundation, USDA-NIFA Multistate Project W3147, the New Jersey Agricultural Experiment Station, National Council of Science and Technology of Mexico and the Program of Estancias Sabaticas y Posdoctorales para la Consolidacion de Grupos de Investigacion (fellowship number 186241), Proyectos de Desarrollo Cientifico para atender Problemas Nacionales (CONACYT 212875) and Project 207400 of Bilateral Cooperation México-Brazil funded by CONACYT and CNPq (Brazil, No. 490440/2013-4). We also acknowledge Cristobal Fonseca-Sepulveda for conducting nitrogen fixation tests on $B$ tequilensis, and Joan W. Bennett for reviewing an early draft of this manuscript.

\section{Author contributions}

M.J.B.-G., P.D.M. \& J.F.W. developed the concept of the experiments and analyses. M.J.B.-G., F.M.P., K.R.P. and M.S.T. implemented experiments. F.M.P., K.R.P., M.H.G.M., 
L.F.Y. \& M.J.K. conducted biochemical analyses. M.S.T. isolated and identified bacteria. All authors contributed to data interpretation and writing of the manuscript.

\section{Additional information}

Supplementary information accompanies this paper at http://www.nature.com/ scientificreports

Competing financial interests: The authors declare no competing financial interests.
How to cite this article: Beltran-Garcia, M.J. et al. Nitrogen acquisition in Agave tequilana from degradation of endophytic bacteria. Sci. Rep. 4, 6938; DOI:10.1038/srep06938 (2014).

(c) (i) This work is licensed under a Creative Commons Attribution 4.0 International License. The images or other third party material in this article are included in the article's Creative Commons license, unless indicated otherwise in the credit line; if the material is not included under the Creative Commons license, users will need to obtain permission from the license holder in order to reproduce the material. To view a copy of this license, visit http://creativecommons.org/licenses/by/4.0/ 